\title{
DAUN MANGGA (Mangifera indica L): POTENSI BARU PENYEMBUH LUKA SAYAT
}

\section{Mango Leaves (Mangifera indica L): A new potent of a healing wound for the incision}

\author{
Arista Mutiara Risa, Yuni Pantiwati, Nurul Mahmudati, \\ Husamah, Fuad Jaya Miharja* \\ Program Studi Pendidikan Biologi Universitas Muhammadiyah Malang, Malang, \\ Jawa Timur, Indonesia \\ *Corresponding author: fuad.jayamiharja@umm.ac.id
}

\begin{abstract}
The use of antiseptics in wounds can cause long-term side effects. This study aims to determine the potential of mango leaves (Mangifera indica L) as a natural ingredient for healing wounds. This true experimental research used six treatment groups. This study used a completely randomized design of four repetitions using 24 samples of white rats (Rattus norvegicus) taken randomly. The results of the Anova statistical test showed that there was a difference in the effect of giving mango leaf extract to incisive wound healing. The results showed that a concentration of $20 \%$ showed a faster recovery time of 7.25 days with an average wound closure of $4.02 \mathrm{~mm}$. This indicates that the extract of mango leaves has the potential to be used as a healing wound for the incision.
\end{abstract}

Key Words: Mango leaves; extract; wound healing

\section{PENDAHULUAN}

Luka terbuka sering terjadi dalam kehidupan sehari-hari, jika dibiarkan dan tidak diobati dapat berpotensi mengalami infeksi seperti gangren, tetanus, dan sebagainya. Upaya untuk mencegah terjadinya infeksi, dibutuhkan obat luka yang bersifat antiseptik, salah satunya adalah povidone iodine yang sering dipakai di kalangan masyarakat. Povidone iodine cocok untuk mengobati infeksi yang diakibatkan oleh bakteri atau 
mikroorganisme lain. Namun povidone iodine ternyata mempunyai dampak negatif, seperti dapat menyebabkan iritasi pada luka, reaksi toksik, kulit terbakar, perubahan warna kulit dan menghambat pembentukan fibroblas (Atik \& Iwan, 2009; Balin \& Pratt, 2002; Rahmawati, 2014; Vogt et al., 2006).

Adanya dampak negatif tersebut menyebabkan timbulnya pergeseran perspektif dari penggunaan bahan kimia ke bahan yang bersifat alami. Hingga saat ini, banyak riset telah dilakukan untuk menemukan ekstrak bahan alami yang dapat menstimulasi dan meningkatkan regenerasi penyembuhan luka (Amaliya, Soemantri, \& Utami, 2013; Wijaya, Citraningtyas, \& Wehantouw, 2014; Yanti, Afrianti, \& Afriani, 2011). Penggunaan ekstrak bahan alami umumnya merupakan kebiasaan yang dilakukan oleh masyarakat tradisional secara turun-temurun. Ekstrak bahan alami merupakan agen penyembuh luka yang mampu melawan infeksi dan mempercepat penyembuhan luka (Ferdinandez, Dada, \& Damriyasa, 2013). Kemampuan penyembuhan luka tidak lepas dari kandungan senyawa aktif dalam bahan alami tersebut seperti alkaloid, saponin, tanin, dan flavonoid (Hasibuan, Yuniwarti, \& Suedy, 2015). Keberadaan senyawa metabolit tersebut berperan penting dalam reaksi biokimia sebagai pemacu proliferasi pada saat pembentukan fibroblas dan kolagen.

Salah satu tanaman yang memiliki kandungan metabolit tersebut adalah mangga (Mangifera indica L). Pemanfaatan mangga masih terbatas pada konsumsi buah, padahal daun mangga merupakan bagian tubuh potensial yang pemanfaatannya belum optimal. Namun demikian sudah banyak penelitian yang menggunakan daun mangga sebagai zat anti bakteri, anti diabetes, dan sebagai antijamur (Kurniasih, 2016; Ningsih, Zusfahair, \& Mantari, 2017; Syah, Suwendar, \& Mulqie, 2015). Penelitian ini bertujuan untuk mengetahui pengaruh pemberian ekstrak daun mangga (Mangifera indica L.) terhadap penyembuhan luka sayat pada tikus putih (Rattus norvegicus).

\section{METODE PENELITIAN}

Penelitian ini dilaksanakan di Laboratorium Kimia Universitas Muhammadiyah Malang pada bulan Maret hingga April 2018. Jenis penelitian adalah true experimental research 
dengan menggunakan daun mangga (Mangifera indica L.) varietas Manalagi. Populasi dalam penelitian ini adalah tikus putih jantan umur 2 bulan dan berat badan kira-kira 150-200 gr yang diperoleh dari "Wistar Farm" Malang. Sampel yang digunakan sebanyak 24 ekor tikus putih yang dibagi dalam 6 kelompok yaitu kelompok kontrol positif, kontrol negatif, 4 kelompok perlakuan yaitu konsentrasi 5\%, 10\%, 15\% dan 20\%. Teknik pengambilan sampel yang digunakan adalah simple random sampling.

Parameter yang diamati adalah penyembuhan luka sayat, meliputi panjang luka sayat, lama waktu hilangnya eritema, lama waktu hilangnya edema/pembengkakan, lama waktu hilangnya granulasi, dan lama waktu yang dibutuhkan dalam penyembuhan luka sayat. Teknik pengambilan data dengan cara observasi pengukuran (mm) dan waktu (hari). Teknik analisis data dengan menggunakan uji One Way Anova dan uji Duncan's. Variabel bebas yang digunakan adalah ekstrak dari daun mangga (Mangifera indica L.) dengan berbagai konsentrasi yaitu 5\%, 10\%, 15\%, dan $20 \%$. Variabel terikat yang digunakan adalah penyembuhan luka sayat. Variabel kontrol yang digunakan adalah jenis kelamin, umur, jenis pakan, jenis minuman, ukuran kandang.

Proses pembuatan dan cara penggunaan ekstrak yang dilakukan meliputi: 1) pemilihan daun mangga dan memisahkan dari tangkainya, 2) pencuci dan mengeringanginkan 1000 gram daun mangga, dipotong kecil dan diblender, 3) memasukkan tumbukan daun mangga ke dalam erlenmayer dan menuangkan etanol PA 96\% sebanyak 2 liter yang dibagi menjadi 4 tempat, masing-masing 250 gr daun mangga diberi $500 \mathrm{ml}$ etanol PA 96\%, 4) maserasi selama $2 \times 24$ jam dan mengambil filtratnya., 5) evaporasi filtrat menggunakan rotary evaporator dengan suhu $\left.69^{\circ} \mathrm{C}-80{ }^{\circ} \mathrm{C}, 6\right)$ Penyimpanan dalam oven dengan suhu $70^{\circ} \mathrm{C}, 7$ ) pembuatan ekstrak daun mangga dengan cara mengencerkan menggunakan aquadest.

Ekstrak yang dihasilkan diaplikasikan dengan cara meneteskan sebanyak 3 tetes pada luka sayat. Ekstrak disimpan didalam lemari pendingin setelah digunakan. 


\section{HASIL DAN PEMBAHASAN}

Berdasarkan hasil pengamatan perlakuan ekstrak daun mangga (Mangifera indica L.) terhadap penyembuhan luka sayat pada tikus putih, disajikan pada Tabel 1 berikut:

\section{Tabel 1}

Hasil uji one way ANOVA

\begin{tabular}{llcc}
\hline No & \multicolumn{1}{c}{ Parameter } & F. hitung & Sig \\
\hline 1. & Panjang luka & 12.737 & 0.000 \\
2. & Eritema & 5.432 & 0.002 \\
3. & Edema & 6.232 & 0.002 \\
4. & Granulasi & 4.171 & 0.011 \\
5. & Lama Penyembuhan & 4.012 & 0.013 \\
\hline
\end{tabular}

Hasil analisis data pada Tabel 1 menunjukkan bahwa terdapat pengaruh nyata antara perlakuan ekstrak daun mangga (Mangifera indica L.) dengan perlakuan kontrol yang terhadap keseluruhan parameter, meliputi rerata panjang luka sayat tikus putih (Rattus norvegicus), lama waktu hilangnya eritema, lama waktu hilangnya edema, lama waktu hilangnya granulasi dan pada lama penyembuhan luka.

Tabel 2

Hasil Uji Duncan's

\begin{tabular}{|c|c|c|c|c|c|c|c|c|c|c|c|}
\hline \multirow{3}{*}{$\begin{array}{l}\text { No } \\
1\end{array}$} & \multirow{3}{*}{$\begin{array}{c}\text { Perlakuan } \\
20 \%\end{array}$} & \multicolumn{10}{|c|}{ Parameter } \\
\hline & & \multicolumn{2}{|c|}{$\begin{array}{c}\text { Panjang } \\
\text { (mm) }\end{array}$} & \multicolumn{2}{|c|}{$\begin{array}{c}\text { Eritema } \\
\text { (hari) }\end{array}$} & \multicolumn{2}{|c|}{$\begin{array}{c}\text { Edema } \\
\text { (hari) }\end{array}$} & \multicolumn{2}{|c|}{$\begin{array}{l}\text { Granulasi } \\
\text { (hari) }\end{array}$} & \multicolumn{2}{|c|}{$\begin{array}{c}\text { Lama } \\
\text { Waktu } \\
\text { (hari) }\end{array}$} \\
\hline & & $a$ & 4.02 & $a$ & 4.50 & $a$ & 7.25 & $a$ & 6.00 & $\mathrm{a}$ & 7.25 \\
\hline 2 & $15 \%$ & $\mathrm{Ab}$ & 5.46 & $a b$ & 5.00 & $a b$ & 9.00 & $\mathrm{~b}$ & 9.00 & $\mathrm{~b}$ & 9.75 \\
\hline 3 & $10 \%$ & $\mathrm{Bc}$ & 6.77 & $a b$ & 5.50 & $\mathrm{~b}$ & 9.50 & $\mathrm{~b}$ & 9.75 & $\mathrm{~b}$ & 10.00 \\
\hline 4 & $5 \%$ & $\mathrm{C}$ & 7.70 & $\mathrm{~b}$ & 5.75 & $\mathrm{~b}$ & 10.00 & $\mathrm{~b}$ & 10.00 & $\mathrm{~b}$ & 10.25 \\
\hline 5 & Kontrol (+) & C & 7.86 & $\mathrm{~b}$ & 5.75 & $\mathrm{~b}$ & 10.00 & $\mathrm{~b}$ & 10.25 & $\mathrm{~b}$ & 10.75 \\
\hline 6 & Kontrol (-) & D & 9.70 & c & 7.00 & c & 12.25 & $\mathrm{~b}$ & 12.25 & $\mathrm{~b}$ & 12.25 \\
\hline
\end{tabular}

Keterangan: a, b, c: perbedaan notasi menunjukkan adanya perbedaan yang signifikan antar perlakuan

Berdasarkan hasil uji duncan's pada Tabel 2, diketahui bahwa keempat konsentrasi ekstrak daun mangga berbeda secara nyata dengan kontrol negatif, tetapi konsentrasi 20\% berbeda secara nyata dengan kedua kelompok kontrol, dan konsentrasi 
20\% merupakan konsentrasi terbaik dalam penyembuhan panjang luka sayat pada tikus putih (Rattus norvegicus). Hal ini dikarenakan daun mangga mengandung senyawa yang mampu menyembuhkan luka sayat, antara lain saponin, tanin, dan flavonoid (Shah, Patel, \& Parmar 2010), sedangkan pada kontrol positif yang menggunakan povidone iodine juga dapat mempercepat penyembuhan luka. Mekanisme kerja povidone iodine bekerja terjadi setelah kontak langsung dengan jaringan, elemen iodine akan dilepaskan secara perlahan dengan cara menghambat metabolisme enzim bakteri sehingga mengganggu multiplikasi bakteri dan bakteri menjadi lemah (Yunitasari, Alifiar, \& Priatna, 2016). Berbeda dengan kontrol negatif, pemulihan luka berlangsung lebih lama dibandingkan kelompok perlakuan (ekstrak daun mangga) dan kelompok kontrol positif (povidone iodine 10\%), hal ini dikarenakan kelompok kontrol negatif tidak diberikan zat aktif yang dapat mempercepat penyembuhan luka, sehingga penyembuhan luka terjadi secara alami, dimana penyembuhan akan terjadi sesuai proses fisiologis tubuh (Yunitasari et al., 2016).

Proses penyembuhan luka sayat secara fisiologis dibagi menjadi tiga fase yaitu fase inflamasi, proliferasi, dan maturasi. Inflamasi bertujuan untuk membersihkan area luka dari kontaminasi bakteri serta menghentikan pendarahan. Pada tahap ini juga terbentuk eritema pada luka sayat tikus putih, suatu area yang tampak berwarna kemerahan (Sugiaman, 2011). Berdasarkan lama waktu hilangnya eritema, diketahui bahwa keempat konsentrasi ekstrak daun mangga berbeda secara nyata dengan kontrol negatif, tetapi konsentrasi 5\%, 10\% dan 15\% tidak berbeda secara nyata dengan kontrol positif, namun konsentrasi $20 \%$ berbeda secara nyata dengan kelompok kontrol dan memiliki rata-rata waktu penyembuhan eritema yang lebih singkat. Kandungan flavonoid dalam ekstrak daun mangga diyakini menurunkan derajat eritema pada luka (Ibad, Nasution, \& Andarini, 2013). Selain itu, pada fase inflamasi ini flavonoid memiliki peran antibakteri, sehingga mampu menghambat pertumbuhan bakteri dengan cara denaturasi protein yang menyebabkan gangguan dalam pembentukan sel, sehingga merubah komposisi komponen protein, ketika fungsi membran 
sel terganggu, menyebabkan peningkatan permeabilitas sel sehingga terjadi kerusakan sel bakteri, dan sel bakteri akan mati (Liantari, 2014). Fungsi lain dari flavanoid pada fase ini adalah menghambat pendarahan dengan cara meningkatkan jumlah trombosit, ketika tubuh mengalami pendarahan maka trombosit akan pecah yang menghasilkan enzim trombokinase, selanjutnya akan bekerja sebagai enzim untuk mengaktifkan molekul fibrinogen membentuk fibrin, dibantu oleh ion $\mathrm{Ca}$ dan vitamin $\mathrm{K}$ yang terdapat pada plasma darah (Hasibuan et al., 2015). Hasil pengamatan pada tahap inflamasi seperti pada Gambar 1.

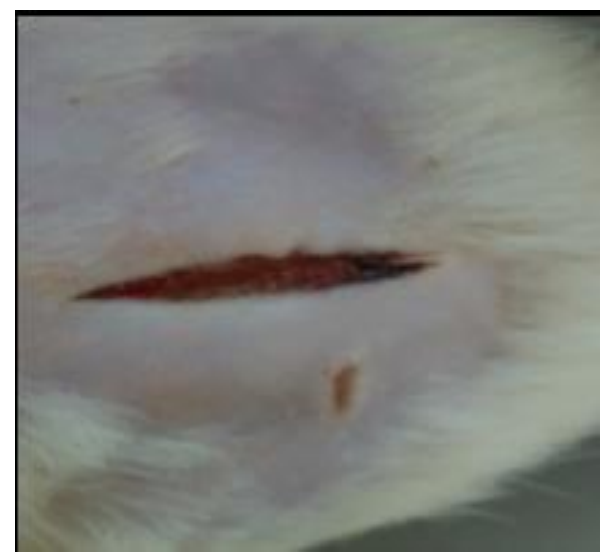

Gambar 1. Fase inflamasi yang terjadi pasca terbentuknya luka

Tahap proliferasi ditandai dengan terjadi pembengkakan dan granulasi pada luka sayat. Berdasarkan lama waktu hilangnya pembengkakan luka sayat pada tikus putih, diketahui bahwa keempat konsentrasi ekstrak daun mangga berbeda secara nyata dengan kontrol negatif, tetapi konsentrasi 5\%, 10\%, dan 15\% tidak berbeda secara nyata dengan kontrol positif, namun konsentrasi $20 \%$ berbeda secara nyata dengan kedua kelompok kontrol dan merupakan konsentrasi terbaik dalam penyembuhan lama waktu hilangnya pembengkakan pada luka sayat tikus putih (Rattus norvegicus). Hilangnya pembengkakan ini dikarenakan kandungan senyawa tanin pada ekstrak daun mangga, menurut Izzati (2015) tanin mampu menurunkan permeabilitas kapiler dan mengurangi pembengkakan jaringan serta menghindari terbentuknya pus pada permukaan luka akibat invasi patogen 
yang bisa menghambat penyembuhan. Selain terjadi proses pembengkakan, pada fase proliferasi ini juga terjadi proses granulasi (Gambar 2).

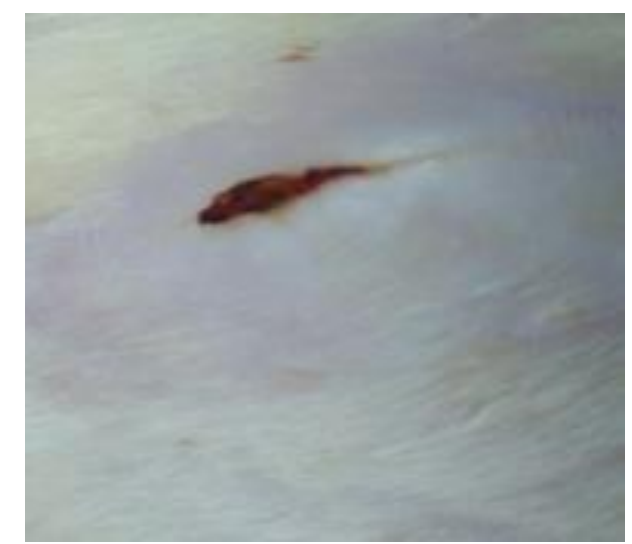

Gambar 2. Fase proliferasi ditandai dengan granulasi di area sekitar luka

Berdasarkan lama waktu hilangnya granulasi luka sayat pada tikus putih diketahui bahwa konsentrasi $20 \%$ ekstrak daun mangga berbeda secara nyata dengan kedua kelompok kontrol dan konsentrasi ekstrak yang lain, namun konsentrasi 5\%, 10\%, $15 \%$ dan kelompok kontrol tidak berbeda nyata, dan konsentrasi $20 \%$ merupakan konsentrasi terbaik dalam penyembuhan lama waktu hilangnya granulasi pada luka sayat tikus putih (Rattus norvegicus), hal ini dikarenakan kandungan senyawa saponin pada ekstrak daun mangga, dimana saponin dapat memicu vascular endothelial growth factor (VEGF) dan meningkatkan jumlah makrofag yang bermigrasi ke area luka, sehingga meningkatkan produksi sitokin yang akan mengaktifkan fibroblas di jaringan luka, kemudian memacu pembentukan kolagen yang mempunyai peran dalam proses penyembuhan luka (Kusumawardhani, Kalsum, \& Rini, 2015). 


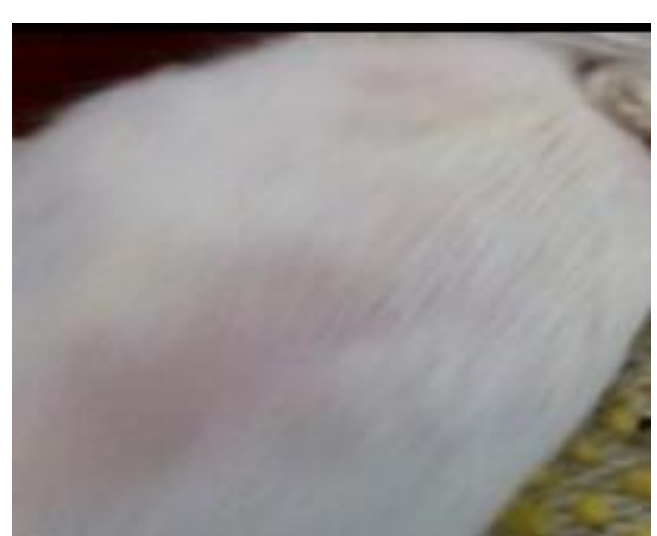

Gambar 3. Fase maturasi ditandai dengan terbentuknya jaringan baru yang utuh dan lebih kuat

Tahap terakhir adalah fase maturasi atau remodeling. Tahap ini ditandai dengan penyempurnaan jaringan baru menjadi utuh dan kuat (Gambar 3). Berdasarkan lama proses penyembuhan luka sayat tikus putih diketahui bahwa konsentrasi $20 \%$ ekstrak daun mangga berbeda secara nyata dengan kedua kelompok kontrol dan konsentrasi ekstrak yang lain, namun konsentrasi 5\%, 10\%, 15 dan kelompok kontrol tidak berbeda nyata, dan konsentrasi $20 \%$ berbeda secara nyata dengan kedua kelompok kontrol dan merupakan konsentrasi terbaik dalam lama penyembuhan luka sayat tikus putih (Rattus norvegicus), hal ini dikarenakan kandungan senyawa pada daun mangga seperti flavonoid, tanin, dan saponin.

\section{KESIMPULAN}

Pemberian konsentrasi ekstrak daun mangga (Mangifera indica L) berpotensi mempercepat proses penyembuhan luka sayat pada tikus putih (Rattus norvegicus) dibandingkan dengan perlakuan kontrol. Ekstrak daun mangga (Mangifera indica L) konsentrasi $20 \%$ merupakan konsentrasi yang paling efektif dalam proses penyembuhan luka. 


\section{DAFTAR PUSTAKA}

Amaliya, S., Soemantri, B., \& Utami, Y. W. (2013). Efek ekstrak daun pegagan (Centella asiatica) dalam mempercepat penyembuhan luka terkontaminasi pada tikus putih (Rattus novergicus) galur wistar. Ilmu Keperawatan, 1(1), 19-25. Retrieved from http://www.jik.ub.ac.id/index.php/jik/article /view/32/78

Atik, N., \& Iwan, J. A. (2009). Perbedaan efek pemberian topikal gel lidah buaya (Aloe vera l.) dengan solusio povidone iodine terhadap penyembuhan luka sayat pada kulit mencit (Mus musculus). Majalah Kedokteran Bandung, 41(2), 29-36. https://doi.org/10.15395/mkb.v41n2.188

Balin, A. K., \& Pratt, L. (2002). Dilute povidone-iodine solutions inhibit human skin fibroblast growth. Dermatologic Surgery, 28(3), 210-214. https://doi.org/10.1046/j.1524-4725.2002. 01161.x

Ferdinandez, M. K., Dada, I. K. A., \& Damriyasa, I. M. (2013). Bioaktivitas ekstrak daun tapak dara (Catharantus roseus) terhadap kecepatan angiogenesis dalam proses penyembuhan luka pada tikus wistar. Indonesia Medicus Veterinus, 2(2), 180-190.

Hasibuan, F. N., Yuniwarti, E. Y. W., \& Suedy, S. W. A. (2015). Effect of Psidium guajava Linn . leaves and Anacardium occidentale Linn. leaves on wound healing to Mus musculus Linn. skin. Traditional Medicine Journal, 20(1), 24-27.

Ibad, M. R., Nasution, T. H., \& Andarini, S. (2013). Pengaruh ekstrak daun kersen (Muntingia calabura) terhadap derajat eritema pada proses inflamasi marmut (Cavia porcellus) dengan luka bakar derajat II dangkal. Ilmu Keperawatan, 1(November), 157-161.

Izzati, U. Z. (2015). Efektivitas Penyembuhan Luka Bakar Salep Ekstrak Etanol Daun Senggani ( Melastoma malabathricum L 
.) Pada Tikus ( Rattus norvegicus ). Skripsi.

Kurniasih, R. (2016). Pengaruh konsentrasi ekstrak etanol daun mangga arumanis muda (Mangifera indica L.) terhadap hambatan pertumbuhan bakteri Streptococcus mutans in vitro. University of Muhammadiyah Surakarta.

Kusumawardhani, A. D., Kalsum, U., \& Rini, I. S. (2015). Effect of Betel Leaves Extract Oinment ( Piper betle Linn .) on the Number of Fibroblast in IIA Degree Burn Wound on Rat ( Rattus norvegicus ) Wistar Strain Luka bakar adalah luka pada kulit atau jaringan lain yang disebabkan oleh panas atau terkena radia, $2,16-28$.

Liantari, D. S. (2014). Effek of Wuluh Starfruit Leaf Extrac For Sreptococcus mutans Growth. J. Mayority, 3(7), 27-33.

Ningsih, D. R., Zusfahair, Z., \& Mantari, D. (2017). Ekstrak daun mangga (Mangifera indica L.) sebagai antijamur terhadap jamur Candida albicans dan identifikasi golongan senyawanya. Jurnal Kimia Riset, 2(1), 61-68.

Rahmawati, I. (2014). Perbedaan efek perawatan luka menggunakan gerusan daun petai cina (Leucaena glauca, Benth) dan povidon iodine $10 \%$ dalam mempercepat penyembuhan luka bersih pada marmut (Cavia porcellus). Jurnal Wiyata, 1(2), 227-234.

Sugiaman, V. K. (2011). Peningkatan Penyembuhan Luka di Mukosa Oral Melalui Pemberian Aloe Vera ( Linn .) Secara Topikal Topical. Jkm, 11(1), 70-79.

Syah, M. I., Suwendar, \& Mulqie, L. (2015). Uji Aktivitas Antidiabetes Ekstrak Etanol Daun Mangga Arumanis (Mangifera Indica L. "Arumanis") pada Mencit Swiss Webster Jantan dengan Metode Tes Toleransi Glukosa Oral (Ttgo). Prosiding Penelitian Sivitas Akademika UNISBA, 297-303. 
Vogt, P. M., Reimer, K., Hauser, J., Roßbach, O., Steinau, H. U., Bosse, B., ... Fleischer, W. (2006). PVP-iodine in hydrosomes and hydrogel-A novel concept in wound therapy leads to enhanced epithelialization and reduced loss of skin grafts. Burns, 32(6), 698-705. https://doi.org/10.1016/j.burns. 2006.01.007

Wijaya, B. A., Citraningtyas, G., \& Wehantouw, F. (2014). Potensi ekstrak etanol tangkai daun talas (Colocasia esculenta [L]) sebagai alternatif obat luka pada kulit kelinci (Oryctolagus cuniculus). PHARMACON Jurnal Ilmiah Farmasi, 3(3), 23022493.

Yanti, R., Afrianti, R., \& Afriani, L. (2011). Formulasi krim ekstrak etanol daun kirinyuh (Euphatorium odoratum. l) untuk penyembuhan luka. Majalah Kesehatan PharmaMedika, 3(1), 227-230. Retrieved from http://academicjournal.yarsi.ac.id/ index.php/majalah-Pharamedika/article/view/440

Yunitasari, D., Alifiar, I., \& Priatna, M. (2016). Uji aktivitas ekstrak etanol daun jengkol (Pithecellobium lobatum Benth) terhadap penyembuhan luka insisi pada tikus putih jantan galur wistar. Farmasi Sains Dan Praktis, II(1), 30-35. 